\title{
IDENTIFIKASI KARAKTERISTIK SEKTOR INFORMAL DI PROVINSI JAWA TIMUR
}

\author{
Dhika Amalia Kurniawan \\ University Of Darussalam Gontor \\ Email: dhika.amalia@unida.gontor.ac.id
}

\begin{abstract}
This study aims to explore further information about the background, the profile of the informal sectors sector in east java. The identification results can be utilized in various matters : policy formulation, identify problems informal sectormapping of a strategy to build competitive advantage for informal sectors. This study used quantitative approach and the data collection techniques used are survey methods using questionnaires. Data analysis techniques is descriptive statistic test. The sample used is mostly informal sectors in east java by the number of samples used by 250 respondents. This study shows that the profile of informal sector business actors in East Java can be seen that based on the aspect of gender differences, informal sectors were dominated by respondents with female genitalia. Based on the aspect of marital status, informal sectoris dominated by married respondents with a percentage of $81.6 \%$, based on the aspect of age distribution, informal sectors are dominated by respondents aged 40-49 years, with a percentage of $37.6 \%$. Based on the aspect of education level, East Java informal sectorwas dominated by respondents with high school level education with a percentage of $62.8 \%$. Based on the aspect of ownership of expertise before entrepreneurship, informal sectorwith the same percentage, the respondents already have expertise in entrepreneurship and some do not have expertise before trying. Based on the aspect of the number of full time workers in their business, East Java informal sectoronly has one worker in their business operations, with a percentage of $40.8 \%$.
\end{abstract}

Keyword : Informal Sector, East Java, Bussiness.

\begin{abstract}
ABSTRAK
Penelitian ini bertujuan untuk menggali informasi lebih lanjut tentang latar belakang, profil sektor sektor informal di Jawa Timur. Hasil identifikasi dapat dimanfaatkan dalam berbagai hal: perumusan kebijakan, identifikasi masalah, sekte informal strategi untuk membangun keunggulan kompetitif bagi sektor informal. Penelitian ini menggunakan pendekatan kuantitatif dan teknik pengumpulan data yang digunakan adalah metode survei menggunakan kuesioner. Teknik analisis data adalah uji statistik deskriptif. Sampel yang digunakan sebagian besar adalah sektor informal di Jawa Timur dengan jumlah sampel yang digunakan oleh 250 responden. Studi ini menunjukkan bahwa profil pelaku usaha sektor informal di Jawa Timur dapat dilihat bahwa berdasarkan aspek perbedaan gender, sektor informal didominasi oleh responden dengan alat kelamin perempuan. Berdasarkan aspek status perkawinan, sektor informal didominasi oleh responden yang menikah dengan persentase $81,6 \%$, berdasarkan aspek distribusi usia, sektor informal didominasi oleh responden berusia 40-49 tahun, dengan persentase 37,6\%. Berdasarkan aspek tingkat pendidikan, sektor informal Jawa Timur didominasi oleh responden dengan tingkat pendidikan sekolah menengah atas dengan persentase 62,8\%. Berdasarkan aspek kepemilikan keahlian sebelum berwirausaha, sektor informal dengan persentase yang sama, responden sudah memiliki keahlian dalam berwirausaha dan sebagian tidak memiliki keahlian sebelum mencoba. Berdasarkan aspek jumlah pekerja penuh waktu dalam bisnis mereka, sektor informal Jawa Timur hanya memiliki satu pekerja dalam operasi bisnis mereka, dengan persentase $40,8 \%$.
\end{abstract}

Kata kunci: Sektor Informal, Jawa Timur, Bisnis. 


\section{JURNAL EKONOMI DAN MANAJEMEN \\ P-ISSN: 2598-9022/ E-ISSN: 2598-9618 \\ Available at:}

http://e-journal.unipma.ac.id/index.php/capital

\section{A. LATAR BELAKANG}

Indonesia merupakan negara terbesar ke 15 di dunia, dengan total penduduk pada tahun 2018 berjumlah sekitar 265 juta jiwa (Badan Pusat Statistik) yang terdiri dari 133,17 juta jiwa laki-laki dan 131,88 juta jiwa perempuan. dengan jumlah penduduk yang tinggi menjadikan negara indonesia memiliki kelebihan dan kekurangan dalam berbagai segi, baik dari segi pendidikan, perekonomian dan juga kesehatan. berbicara tentang perekonomian, maka kondisi ekonomi di Indonesia didukung oleh berbagai sektor usaha antara lain sektor pertanian, perdagangan, industri, pertambangan, transportasi, dan berbagai jenis sektor lainnya, dimana sektor tersebut biasa dikenal dengan sebutan sektor informal. sektor informal merupakan sektor yang memberikan peluang besardalam penyediaan lapangan pekerjaan (Richardson, 1984) selain itu menurut data BPS sektor informal adalah sektor yang berkontribusi besar terhadap pertumbuhan ekonomi negara indonesia. berdaarkan fakta tersebut disimpulkan bahwa mayoritas masyarakat indonesia bekerja dalam bidang informal baik skala kecil, menengah hingga skala besar.

Sektor informal menjadi penopang perekonomian di Indonesia dan mampu memberikan sumbangan produk domestik bruto (PDB) kepada negara sebesar 60,34\% menciptakan lapangan kerja untuk hampir 108 juta orang indonesia. PDB adalah jumlah nilai tambah yang dihasilkan oleh seluruh unit usaha dalam suatu negara tertentu, atau merupakan jumlah nilai barang dan jasa akhir yang dihasilkan oleh seluruh unit ekonomi. dapat diartikan bahwa sektor informal sebagai salah satu tombak suatu negara khusunya Indonesia dalam upaya mengentaskan pengangguran dan peningkatan perekonomian di Indonesia. dengan kondisi tersebut, menjadi tugas wajib bagi pemerintah, lembaga maupun berbagai pihak lain untuk dapat mengembangkan sektor informal di seluruh wilayah di Indonesia, salah satunya provinsi Jawa Timur. Jawa Timur merupakan salah satu provinsi dengan jumlah penduduk terbanyak dengan 


\section{JURNAL EKONOMI DAN MANAJEMEN \\ P-ISSN: 2598-9022/ E-ISSN: 2598-9618 \\ Available at:}

http://e-journal.unipma.ac.id/index.php/capital

peringkat nomor dua dari seluruh provinsi di Indonesia.

Dalam upaya pengembangan sektor informal, baik pemerintah, lembaga maupun pihak lain maka upaya tersebut dapat dilakukan melalui berbagai progam baik melalui edukasi, pelatihan, bantuan dana, pendampingan kewirausahaan maupun progam pengembangan lainnya. dalam menunjang hal tersebut, maka diperlukan profil dan karakteristik sektor informal di Jawa Timur untuk dapat menentukan model pengembangan sektor informal dilihat dalam berbagai segi.

Berangkat dari pemaparan tersebut diatas maka masalah penelitian akan berkisar pada karakteristik sektor informal di Jawa Timur. Adapun perumusan masalah penelitian adalah sebagai berikut "Bagaimana profil sektor informal di Jawa Timur ?" secara umum tujuan yang ingin dicapai dari penelitian ini adalah untuk menggali informasi lebih jauh tentang latarbelakang, profil sektor informaldi Jawa Timur dengan harapan hasil identifikasi dapat dimanfaatkan dalam berbagai hal yaitu perumusan kebijakan, mengidentifikasi masalah yang dihadapi sektor informal, pemetaan tentang suatu strategi yang diharapkan dapat membangun keunggulan bersaing bagi sektor informal sebagai sektor yang memiliki peran penting bagi perekonomian negara Indonesia (Ascarya, 2007).

\section{B. KAJIAN TEORI}

\section{Definisi Sektor Informal}

Menurut Alisjahbana, (2006) sektor informal merupakan suatu kegiatan ekonomi yang dapat dilakukan dengan sumberdaya seadanya, ukuran usaha umumnya kecil,menggunakan teknologi tepat guna dan bersifat padat karya dimana tujuan dari kegiatan tersebut adalah memproduksi barang dan jasa untuk kebutuahan masyarakat. Sedangkan menurut Munkner dan Walter, (2001) sektor informal diartikan sebagai usaha yang dijalanakan dengan aturan-aturan pribadi, ketrampilan sederhana, berproduksi dan melakukan kontrak sendiri terhadap usaha yang dibangun. 


\section{JURNAL EKONOMI DAN MANAJEMEN \\ P-ISSN: 2598-9022/ E-ISSN: 2598-9618 \\ Available at:}

http://e-journal.unipma.ac.id/index.php/capital

Dalam aplikasinya, sektor informal adalah bidang usaha yang paling banyak dilakukan oleh masyarakat, karena mudah untuk dilakukan, mudah dimasuki dan tanpa memerlukan modal besar, menggunakan teknologi sederhana, beroperasi dalam skala kecil, padat karya, selain itu tidak terikat oleh aturan-aturan pemerintahan dan berbagai aturan lainnya (Gibert dan Gugler, 1996). Hal ini dilakukan dengan berbagai alasan yang melatar belakanginya, seperti tingginya jumlah penduduk, lowongan pekerjaan yang terbatas, tingkat pendidikan yang rendah, banyaknya pengangguran dan lain sebagainya. Selain itu sektor informal tumbuh karena dampak persaingan diantara industri-industri besar yang telah siap dalam berkompetisi dengan menggunakan teknologi, managemen yang kuat, modal yang besar dan keunggulan dalam hal produk yang diproduksinya, sehingga menjadikan sektor informal menjadi alternative pekerjaan bagi masyarakat baik dinegara berkembang maupun dinegara yang sedang berkembang.

\section{Keunggulan dan Kelemahan}

\section{Sektor Informal}

Melihat perannya yang begitu penting bagi perkembangan perekonomian suatu negara, sektor informal memiliki kelebihan dan juga kekuranagan bila dipandang dalam berbagai sisi. Beberapa keunggulan yang dimiliki oleh sektor informal antaralain yaitu 1). Padat karya, dimana sektor informal mampu memberikan pekerjaan bagi banyak pihak, dengan menggunakan sistem operasi tradisional, maka sektor informal mampu memberdayakan tenaga manusia untuk menghasilkan barang dan jasa tanpa mengandalkan bantuan teknologi mesin yang canggih.namun hal tersebut tidak berarti bahwa sektor informal tidak menggunakan tekonologi sama sekali, tetapi menggunakan teknologi yang masih sederhana dengan mengutamakan pekerja atau karyawan dalam operasionalnya. 2) keahlian khusus, sektor informal mampu menghasilkan produk-produk hasil keahlian khusus yang dimiliki oleh pelaku usahanya, ketrampilan serta keuletan yang dimiliki mampu 


\section{JURNAL EKONOMI DAN MANAJEMEN \\ P-ISSN: 2598-9022/ E-ISSN: 2598-9618 \\ Available at:}

http://e-journal.unipma.ac.id/index.php/capital

menghasilkan produk yang uniq, khas dan memiliki nilai jual tinggi karena diproduksi dengan keahlian khusus tanpa menggunakan bantuan mesin, seperti batik lukis, lukisan, guci tanah liat, berbagai pernak pernik buatan dan lain sebagainya. 3) modal, permodalan yang digunakan sektor informal adalah dana pribadi atau tabungan, dimana hal ini menunjukkan kemandirian dalam hal permodalan, namun sektor informal ini mulai dapat mengembangkan usahanya dengan mengakses pendanaan dari lembaga keuangan yang menawarkan bagi hasil yang murah khusus untuk modal usaha rakyat.4) daya tahan, dalam keadaan apapun sektor informal telah membuktikan dapat bertahan ditengah keadaan ekonomi yang tidak stabil, bahkan sektor informal dapat berkembang lebih besar dalam melawan keadaan ekonomi yang terjadi.

Selain itu, sektor informal juga memiliki kelemahan antara lain 1) Kegiatan usaha tidak terorganisir dengan baik (Hidayat,1978). 2) Modal yang terbatas 2) Pemasaran yang masih tradisional 3)
Pengetahuan yang terbatas terhadap bisnis, 4) Penguasahaan teknologi yang sangat terbatas (Geertz, 1963).

5) Metode operasi dan produksi yang masih kecil dan tradisional (Boeke, 1953) dan lain sebagainya.

\section{METODE PENELITIAN}

Rancangan yang menjadi obyek penelitian ini adalah profil usaha mikro kecil menengah (informal) di provinsi Jawa Timur. penelitian ini ditargetkan di wilayah Jawa Timur karena merupakan provinsi dengan jumlah informal sebanyak 9,59 juta, selain itu informal Jawa Timur memberikan sumbangan produk domistik regional bruto (PDRB) sebanyak 74,36 \% pada tahun 2018 terhadap provinsi Jawa Timur. Penelitian ini dilakukan dengan tujuan untuk mengetahui profil dari informal Jawa Timur, dan hasilnya dapat digunakan sebagai bahan dalam pengambilan berbagai kebijakan serta pengembangan usaha tersebut.

Teknik pengumpulan data yang digunakan adalah metode survei dengan menggunakan kuesioner yang diberikan kepada 


\section{JURNAL EKONOMI DAN MANAJEMEN \\ P-ISSN: 2598-9022/ E-ISSN: 2598-9618 \\ Available at:}

http://e-journal.unipma.ac.id/index.php/capital

responden dalam penelitian. Populasi dalam penelitian ini adalah seluruh pelaku usaha informal di Jawa Timur, sedangkan sampel yang digunakan adalah sebagian pelaku informal di Jawa Timur dengan jumlah sampel yang digunakan sebanyak 250 responden/ pelaku informal jawa timur.

Penelitian ini menggunakan nonprobability sampling dengan teknik purposive sampling. Menurut Sugiono, (2015) teknik ini didasarkan pada pertimbangan tertentu yang telah ditetapkan terlebih dahulu,yaitu 1) pelaku informal dengan kriteria usaha yang bergerak dalam bidang kuliner, transportasi dan dagang, 2) usaha dengan metode operasinya menetap atau tidak berpindah-pindah.

Penentuan ini juga didasarkan pada banyaknya usaha informal Jawa Timur yang bergerak dalam bidang tersebut dibandingkan dalam bidang lainnya.

\section{HASIL DAN PEMBAHASAN}

\section{Keadaan Umum Informal Jawa}

\section{Timur}

Jawa Timur merupakan salah satu provinsi yang ada di Indonesia, dengan luas sebesar $47.922 \mathrm{~km}^{2}$, dengan total penduduk di Jawa Timur sejumlah 39, 29 juta jiwa yang terdiri dari 19,4 juta jiwa atau 49,3 persen penduduk laki-laki dan 19,9 juta jiwa atau 50,63 jiwa adalah penduduk perempuan.

Data sensus ekonomi nasional menyatakan bahwa jumlah informal di Jawa Timur sebanyak 9,59 juta, dengan rincian sebanyak 4,61 juta informal bergerak di sektor non-pertanian dan 4,98 juta informal bergerak dalam sektor pertanian. Jawa Timur berkontribusi sebesar $14,85 \%$ terhadap produk domestik bruto nasional.

\section{Hasil Penelitian}

Hasil penelitian ini akan menyajikan profil informal di provinsi Jawa Timur dengan informan yaitu pelaku informal bidang kuliner, dagang dan bidang transportasi sebanyak 250 informan.

\section{Jumlah Responden Berdasarkan}

\section{Gender}

Dapat dilihat dari hasil penelitian ini bahwa pelaku informal di Jawa Timur didominasi 


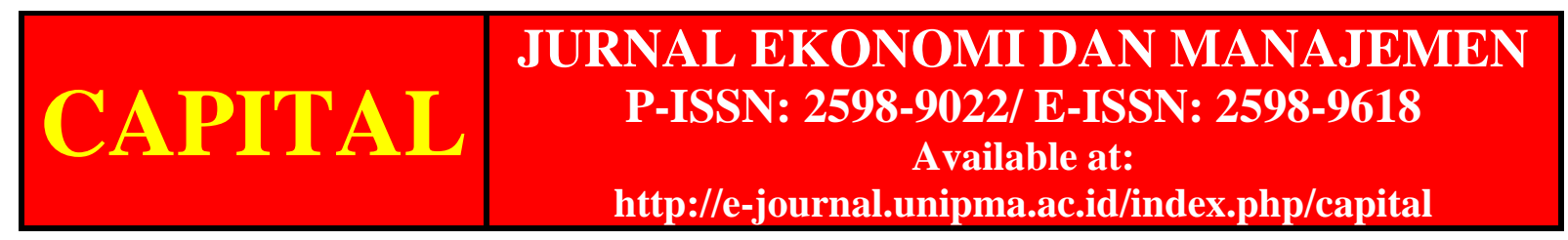

oleh pelaku usaha dengan jenis kelamin perempuan dengan persentase sebanyak $50,8 \%$ dan sisanya sebesar 49,2\% adalah pelaku usaha dengan jenis kelamin laki-laki.

Gender

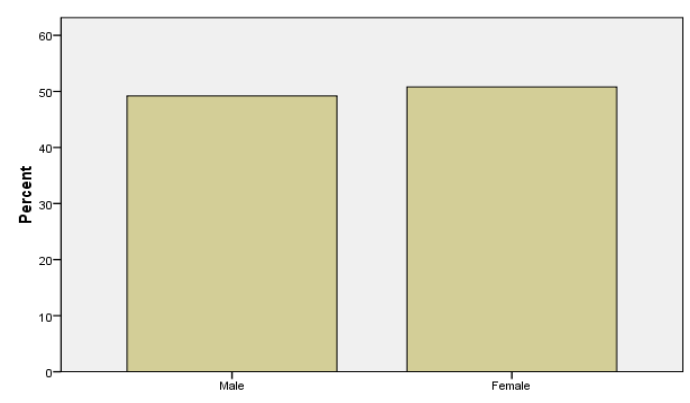

Gambar 1. Perbedaan Jenis Kelamin Responden

\section{Jumlah Responden Berdasarkan}

\section{Status Perkawinan}

Jumlah responden menurut status perkawinannya dapat terlihat pada hasil persentase berikut: bahwa responden pelaku usaha informal Jawa Timur yang berstatus lajang sebanyak 17,6\% , sedangkan yang berstatus kawin/menikah sebanyak $81.6 \%$, dan responden dengan status lainnya sebesar $8 \%$.

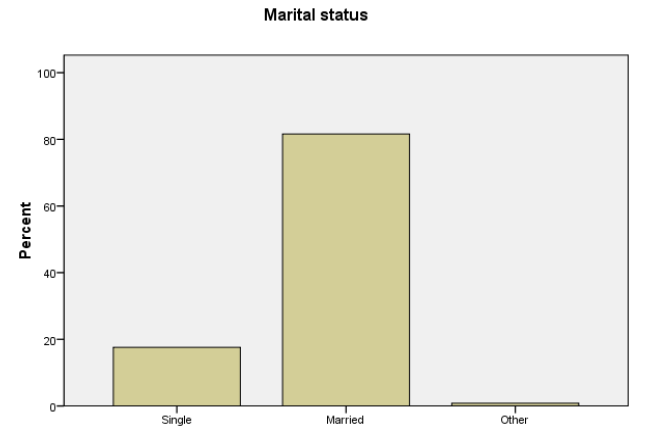

Gambar 2. Status Perkawainan Responden

\section{Jumlah Responden Berdasarkan}

\section{Distribusi Umur}

Dari pelaku usaha informal Jawa Timur sebagai responden, terlihat bahwa kelompok umur responden yang paling banyak berada pada kelompok umur 40-49 tahun dengan persentase sebesar $37,6 \%$, diikuti oleh kelompok umur 30-39 tahun sebesar 33,6\%, dan responden dengan kelompok umur 20 - 29 tahun sebesar $18 \%$, sedangkan yang paling sedikit adalah kelompok umur 50 tahun atau lebih dengan persentase sebesar $10,8 \%$. 


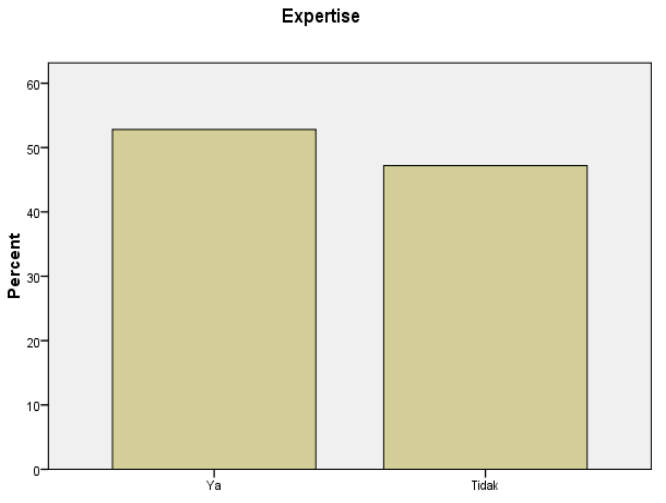

Gambar 3. Perbedaan Umur Responden

\section{Jumlah Responden Berdasarkan}

\section{Tingkat Pendidikan}

Jumlah responden pelaku usaha informal Jawa Timur menurut tingkat pendidikannya, dapat dilihat dengan persentase berikut ini. pelaku informal yang paling banyak adalah lulusan sekolah menengah atau lulusan SLTA (sederajat) sebanyak $62,8 \%$, kemudian disusul oleh pelaku usaha dengan tingkat pendidikan SD sebanyak 16,8\% dan lulusan sarjana atau sederajat dengan persentase sebanyak $14 \%$, sisanya adalah lulusan diploma sebanyak $3,6 \%$ dan pascasarjana sebanyak $1,6 \%$, terakhir adalah pelaku usaha dengan latarbelakang pendidikan non formal sebesar $1,2 \%$.

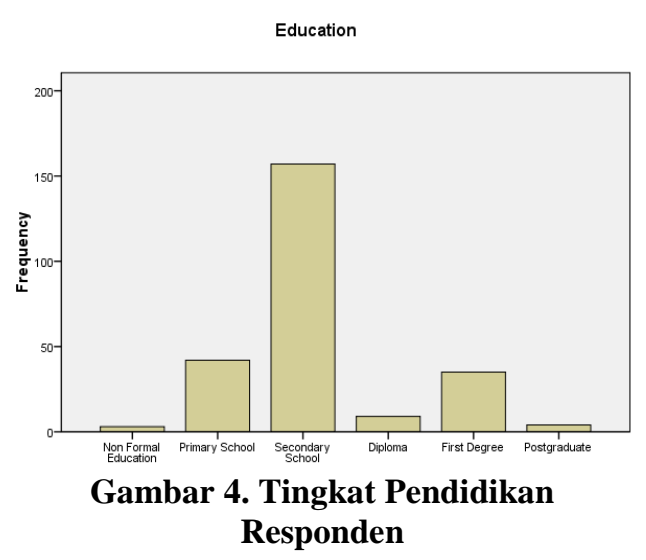

Jumlah Responden Berdasarkan Kepemilikan Keahlian Sebelum Berwirausaha

Hasil penelitian kepada para responden sebagai pelaku usaha informal menunjukkan bahwa responden sebelum melakukan wirausaha mereka telah memiliki dan dibekali keahlian dalam berwirausaha dengan persentase sebesar $52,8 \%$ dan sebagain reponden menyatakan bahwa mereka belum memiliki keahlian dalam berwirausaha dengan persentase sebesar $47,2 \%$. 


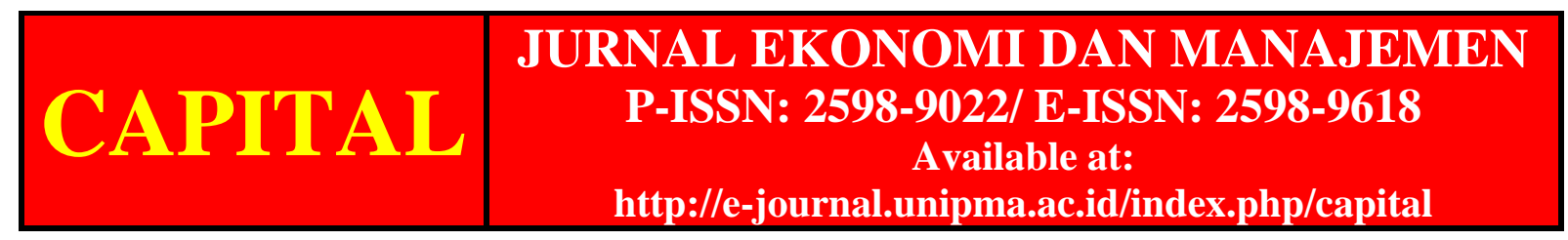

Expertise

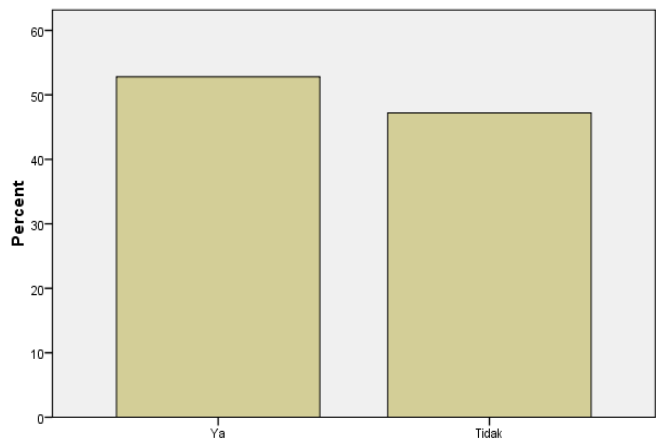

Gambar 5. Status keahlian Responden

\section{Jumlah Responden Berdasarkan}

\section{Banyaknya Pekerja Fulltime}

\section{dalam Usahanya}

Hasil penelitian menunjukkan bahwa banyakmya pekerja fulltime dalam menjalankan usaha informal rata-rata sebanyak 1 pekerja dengan persentase sebesar 40,8\% dan usaha dengan 2 orang pekerja memiliki persentase sebesar $38,8 \%$, sisanya adalah usaha dengan pekerja 3 orang atau lebih.

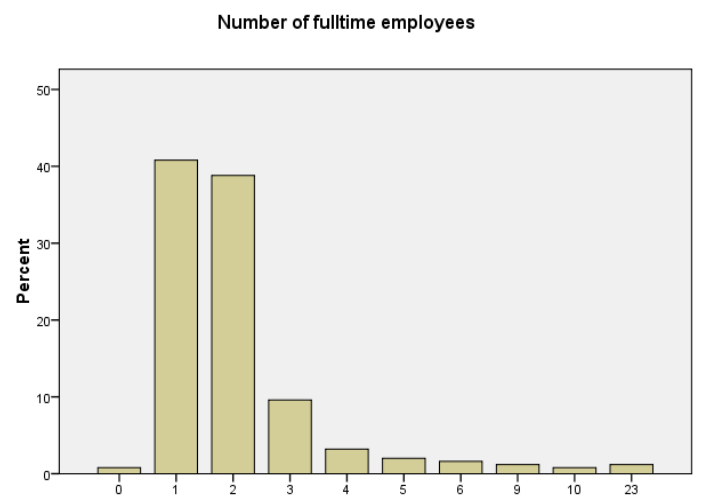

Gambar 6. Jumlah Pekerja dalam Usaha Responden

\section{Jumlah Responden Berdasarkan}

\section{Pendapatan}

Berdasarkan data yang diperoleh pada saat penelitian dilakukan, diperlihatkan bahwa besarnya pendapatan pertahun yang dihasilkan oleh responden adalah pendapatan rp 1 juta -10 juta pertahun sebanyak 9,6\%, penghasilan antara 11 juta hingga 50 juta pertahun adalah 28,4\%, sedangkan pengahsilan informal antara 51 juta - 150 juta pertahun adalah sebesar $18,4 \%$. penghasilan antara 151 juta - 500 juta pertahun dengan persentase sebesar 24,4\%, sisanya adalah informal dengan penghasilan diatas 500 juta pertahun dengan persentase sebesar $19,2 \%$.

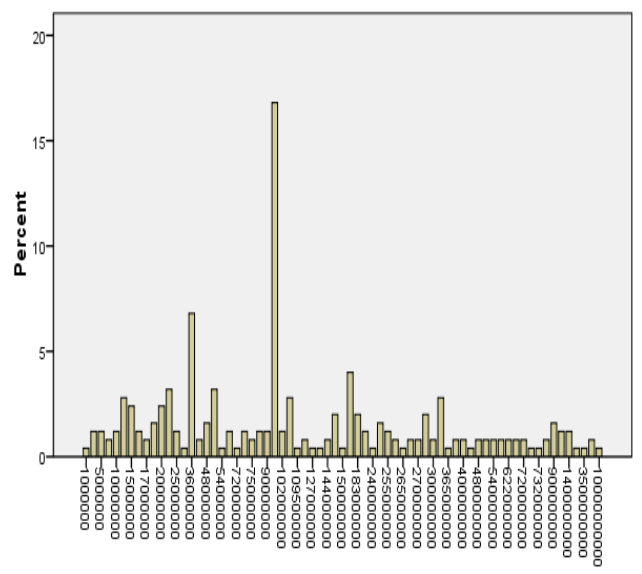

Gambar 7. Total Pendapatan Responden 
Lama Usaha yang Dilakukan

\section{Responden}

Berdasarkan hasil penelitian, lama waktu yang digunakan untuk berusaha bagi pelaku informal Jawa Timuradalah sebagai berikut: lama usaha yang paling banyak dilakukan adalah usaha yang dibangun selama kurang lebih 3 tahun sebanyak 14\%, kemudian sebesar 13,6\% lama usaha sekitar 1 tahun dan $13,2 \%$ adalah usaha yang dibangun dalam waktu sekitar 2 tahun, sisanya adalah usahanya yang dibangun lebih dari 10 tahun persentase terbesar yaitu $55 \%$.

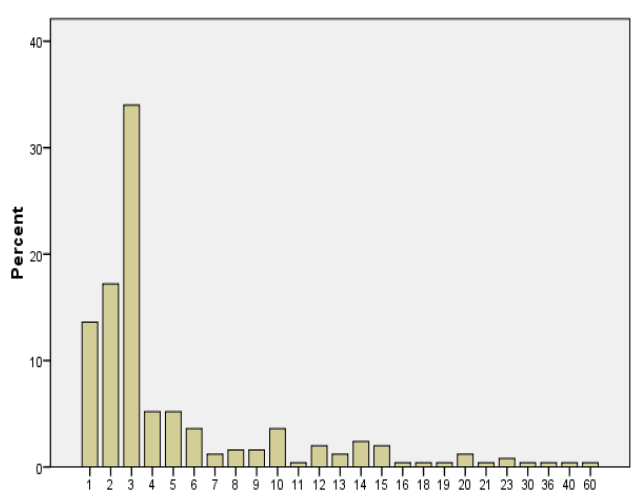

Gambar 8. Lama Usaha Responden

\section{Jumlah Responden Berdasarkan Jumlah Asset dalam Usaha}

Hasil penelitian menunjukkan bahwa usaha informal Jawa Timur yang memiliki jumlah asset antara
Rp 1 juta - 50 juta dengan persentase sebesar $71,2 \%$. sedangkan jumlah asset informal antara 51 juta -100 juta dengan persentase sebesar 6,4\%, sisanya sebesar $22,4 \%$ adalah usaha informal yang memiliki total asset sebesar 100 sampai 800 juta.

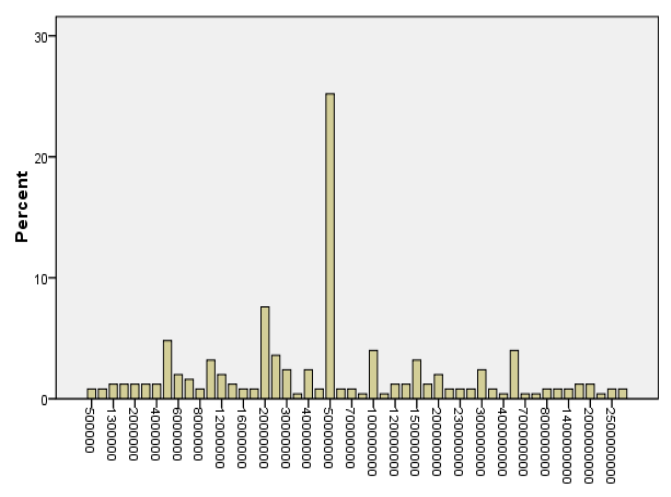

Gambar 9. Jumlah Asset Responden

\section{Responden Berdasarkan Tahun Pendirian Usaha}

Hasil penelitian menunjukkan bahwa responden mendirikan usaha dari tahun 1927 sehingga saat ini, dengan perbedaan antara lain usaha yang dibangun antara tahun 2000 hingga tahun 2010 sebanyak 20,8\%, sedangkan usaha informal yang dibangun antara tahun 2011 hingga 2018 yaitu sebanyak 61,2\%, dan sisanya sebesar $17,2 \%$ adalah usaha informal Jawa Timur yang dibangun sebelum tahun 2000 . 


\section{CAPITAL \\ JURNAL EKONOMI DAN MANAJEMEN \\ P-ISSN: 2598-9022/ E-ISSN: 2598-9618 \\ Available at: \\ http://e-journal.unipma.ac.id/index.php/capital}

Year of business establishment

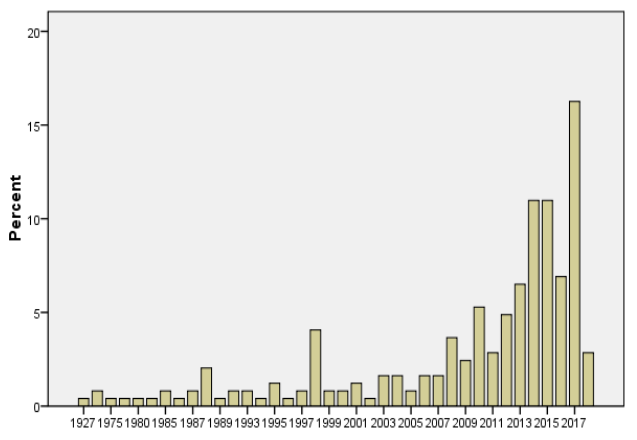

Gambar 10. Tahun Pendirian Usaha Responden

\section{Jumlah Responden Berdasarkan}

\section{Bentuk Badan Usaha}

Hasil penelitian menunjukkan bahwa usaha yang dijalankan oleh responden atau pelaku informal di jawa timur sebesar $60 \%$ adalah usaha milik perorangan/sendiri, kemudian sebesar $8,4 \%$ merupakan usaha dengan bentuk perseroan terbatas (PT), sebesar 7,6\% adalah usaha berbentuk perkongsian (CV), dan sebesar 5,2\% adalah usaha berbentuk koperasi dan sisanya sebesar $16,8 \%$ adalah bentuk usaha dengan bentuk badan hukum lainnya.

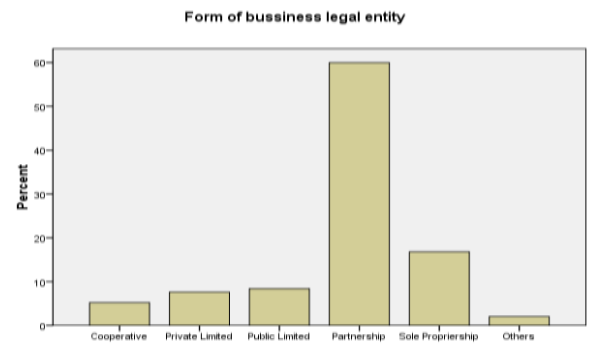

Gambar 11.Bentuk Badan Usaha Responden
Jumlah Responden Berdasarkan

\section{Sektor Usaha Yang Dijalankannya}

Berdasarkan hasil penelitian, menunjukkan bahwa $38,4 \%$ sector bisnis informal berada pada usaha salam bidang perdagangan dan jasa, selanjutnya $24 \%$ usaha dalam menyediakan barang konsumen, $26,8 \%$ pada usaha bidang lain lain, dan sisanya dalam bidang transportasi, industri, kontruksi dan juga pertanian.

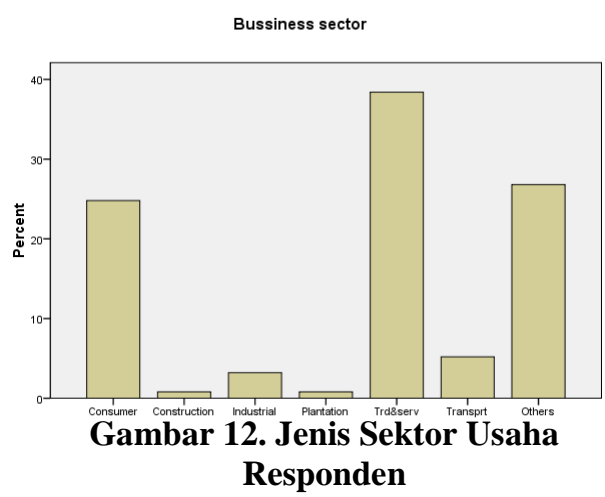

\section{Hasil dan Pembahasan}

Dari hasil penelitian yang dilakukan kepada pelaku informal di jawa timur, maka terdapat 12 (dua belas) variabel penting yang dapat menggambarkan profil informal tersebut. dua belas variable yang diteliti tersebut antaralain yaitu responden dibedakan berdasarkan: perbedaan gender, status perkawinan, distribusi umur, tingkat pendidikan, 
kepemilikan keahlian sebelum berwirausaha, jumlah pekerja fulltime dalam usahanya, pendapatan, lama usaha yang dilakukan responden, jumlah asset dalam usaha, tahun pendirian usaha, bentuk badan usaha, sektor bisnis yang dijalankan.

Berikut ini akan dibahas satu persatu dari variabel tersebut diatas, sehingga hasilnya dapat digunakan dalam pengambilan keputusan oleh berbagai pihak.

\section{Karakteristik Pelaku Informal} Jawa Timur Berdasarkan Gender

Hasil penelitian menunjukkan bahwa sebesar50,8\% pelaku informal Jawa Timur adalah berjenis kelamin perempuan dan 49,2\% adalah pelaku usaha dengan jenis kelamin laki-laki.

Dapat diambil kesimpulan bahwa mayoritas pelaku informal di Jawa Timur saat ini didominasi oleh perempuan, hal ini didukung oleh data Badan Pusat Statistic bahwa penduduk Jawa Timur sebesar $50.63 \%$ didominasi oleh penduduk berjenis kelamin perempuan, sehingga berpotensi besar perempuan sebagai pelaku usahadalam bidang informal.

Hasil ini mengindikasikan bahwa responden dengan jenis kelamin perempuan melakukan usaha dibidang informal dengan alasan untuk membantu perekonomian rumah tangga sebagai penambahan penghasilan keluarga.

2. Karakteristik Pelaku Informal Jawa Timur Berdasarkan Status Perkawinan

Dari hasil penelitian yang berkaitan dengan status perkawinan diketahui bahwa pelaku informal jawa timur yang berstatus menikah sebanyak $81.6 \%$, sedangkan yang berstatus lajang sebanyak $17,6 \%$ dan responden dengan status lainnya sebesar $8 \%$.

Dapat diambil kesimpulan bahwa pelaku informal didominasi oleh pelaku usaha yang telah berkeluarga, hal ini mengindikasikan bahwa responden memiliki tanggung jawab dalam menghidupi keluarganya dengan jalan berwirausaha. Sedangkan responden yang berstatus lajang menjalankan usaha informal 


\section{JURNAL EKONOMI DAN MANAJEMEN \\ P-ISSN: 2598-9022/ E-ISSN: 2598-9618 \\ Available at:}

http://e-journal.unipma.ac.id/index.php/capital

dengan berbagai alasan seperti terbatasnya lowongan pekerjaan, responden yang telah selesai sekolah maupun putus sekolah maupun responden yang ingin mendapatkan pendapatan untuk membantu perekonomian keluarga.

Hal ini sesuai dengan penelitian terdahulu yang dilakukan oleh Riat Aziz, (2016) dalam penelitian terdahulu yang menyatakan hal serupa tentang alasan pelaku usaha informal melakukan usaha tersebut.

3. Karakteristik Pelaku Informal Jawa Timur Berdasarkan Distribusi Umur

Sebesar $37,6 \%$, adalah pelaku informal di jawa timur yang berusia diantara 40-49 tahun, dan sebesar 33,6\%, adalah pelaku informal yang berusia diantara 3039 tahun, selain itu pelaku usaha juga dilakukan oleh kelompok usia 20 - 29 tahun dengan persentase sebesar $18 \%$ dan $10 \%$ adalah pelaku usaha yang berusia diatas 50 tahun.

Dapat disimpulkan bahwa pelaku informal di jawa timur didominasi oleh masyarakat yang berusia produktif dengan persentase terbesar yaitu pelaku usaha yang berumur antara 40-49 tahun dan pelaku yang berusia 30 hingga 39 tahun, hal ini menggambarkan bahwa dalam usia produktif, responden dituntut untuk berproduksi dengan tujuan utama adalah tuntutan ekonomi keluarga, sedangkan pada usia 20 hingga 29 tahun dengan persentase terbesar ke dua, hal ini didorong alasan bahwa usia tersebut adalah adalah usia remaja dan juga usaia anak kuliah sehingga kemungkinan banyak yang melanjutkan pada dunia pendidikan, terakhir adalah pelaku usaha dengan usia diatas 50 tahun dengan persentase terkecil, hal ini dapat dipahami bahwa usia tersebut adalah usia yang tidak produktif untuk seseorang melakukan pekerjaan dalam bidang informal.

4. Karakteristik Pelaku Informal Jawa Timur Berdasarkan Tingkat Pendidikan

Hasil penelitian menunjukkan bahwa mayoritas pelaku informal di Jawa Timur didominasi oleh 


\section{JURNAL EKONOMI DAN MANAJEMEN \\ P-ISSN: 2598-9022/ E-ISSN: 2598-9618 \\ Available at:}

http://e-journal.unipma.ac.id/index.php/capital

masyarakat dengan tingkat pendidikan lulusan sekolah menengah atau lulusan SLTA (sederajat) sebanyak $62,8 \%$. selain itu juga banyak dilakukan oleh masyarakat dengan tingkat pendidikan lulusan Sekolah Dasar sebanyak $16,8 \%$. sisanya adalah pelaku informal dengan tingkat pendidikan lulusan sarjana atau sederajat, lulusan diploma dan juga mereka yang memiliki latarbelakang pendidikan non formal dengan persentase sebesar $20,4 \%$

Dapat disimpulkan bahwa pelaku informal mayoritas adalah masyarakat dengan tingkat pendidikan lulusan SLTA (sederajat), bukan lulusan sarjana maupun diploma. kondisi ini mengindikasikan bahwa usaha informal tidak membutuhkan tingkat pendidikan yang tinggi, selain itutingkat pendidikan pelaku usaha informal di Jawa Timur dapat dikatakan rendah.

5. Karakteristik Pelaku Informal Jawa Timur Berdasarkan
Kepemilikan Keahlian Sebelum

Berwirausaha

Hasil penelitian menunjukkan bahwa sebesar 52,8\% pelaku informal Jawa Timur menyatakan mereka telah memiliki keahlian dalam berwirausaha dan sisanya sebesar $47,2 \%$ belum memiliki keahlian dalam berwirausaha.

Melihat perbandingan tersebut yang tidak memiliki selisih banyak, dapat diambil kesimpulan bahwa pelaku informal yang memiliki keahlian sebelum berwirausaha dan yang tidak memiliki keahlian sebelum berwirausaha berjumlah seimbang.

6. Karakteristik Pelaku Informal Jawa Timur Berdasarkan Jumlah Pekerja Fulltime Dalam Usahanya.

Data hasil penelitian menunjukkan bahwa mayoritas pelaku informal dilakukan oleh satu orang pekerja dengan persentase sebesar $40,8 \%$, selain itu usaha yang dikerjakan oleh dua orang pekerja memiliki persentase sebesar $38,8 \%$, dan sisanya sebesar $20,4 \%$ adalah 


\section{JURNAL EKONOMI DAN MANAJEMEN \\ P-ISSN: 2598-9022/ E-ISSN: 2598-9618 \\ Available at:}

http://e-journal.unipma.ac.id/index.php/capital

usaha yang dikerjakan oleh tiga orang pekerja atau lebih.

Dapat disimpulkan bahwa usaha yang dilakukan dibidang informal adalah usaha skala kecil dengan satu orang pekerja sebagai pemilik dan pelaksana usaha tersebut.

7. Karakteristik Pelaku Informal Jawa Timur Berdasarkan Jumlah Pendapatan

Data hasil penelitian menunjukkan bahwa penghasilan pelaku informal di Jawa Timur memiliki pendapatan pertahun sebesar 11 juta hingga 50 juta pertahun adalah $28,4 \%$, dan pendapatan sebesar 151 juta -500 juta pertahun memiliki persentase sebesar 24,4\%, sisanya adalah usaha informal dengan pendapatan 500 juta pertahun dengan persentase sebesar 19,2\% dan usaha dengan penghasilan Rp 1 juta - 10 juta pertahun sebanyak $9,6 \%$.

Hasil penelitian yang dilakukan terlihat bahwa keuntungan yang diperoleh dari responden beraneka macam. mayoritas pendapatan informal jawa timur didominasi oleh usaha mikro dengan pendapatan sebesar Rp 11juta hingga 50 juta pertahun. kondisi ini dapat dikatakan layak bagi pelaku informal dengan tingkat modal yang digunakan tidak terlalu besar, hal tersebut juga sejalan dengan UU No 20 tentang UMKM di Indonesia.

8. Karakteristik Pelaku Informal Jawa Timur Berdasarkan Lama Usaha Yang Dijalankan.

Data hasil penelitian menunjukkan bahwa usaha yang dilakukan oleh informal Jawa Timur mayoritas telah dilakukan selama kurun waktu lebih dari 10 tahun dengan persentase sebesar $55 \%$. selain itu usaha yang dilakukan dalam waktu sekitar 3 tahun sebanyak $14 \%$, sisanya adalah usaha lain yang sudah dilakukan dalam waktu sekitar 1 sampai 2 tahun dengan persentase sebesar $26,8 \%$.

Dapat diambil kesimpulan bahwa usaha yang dilakukan oleh responden dalam bidang informal mayoritas telah dilakukan selama 


\section{JURNAL EKONOMI DAN MANAJEMEN \\ P-ISSN: 2598-9022/ E-ISSN: 2598-9618 \\ Available at:}

http://e-journal.unipma.ac.id/index.php/capital

lebih dari 10 tahun, hal ini dikarenakan responden berasal dari generasi tua yang melaksanakan usaha tersebut berdasarkan pengalaman dan dilakukan dengan tujuan mencukupi perekonomian keluarga. Hasil tersebut juga mengindikasi bahwa responden tidak mampu bersaing dengan usaha dalam sektor besar dengan keunggulan dan persaingan yang ketat, sehingga tetap bertahan pada usaha yang telah dijalankannya.

Sedangkan pelaku usaha informal yang baru berdiri antara satu sampai tiga tahun dikarenakan alasan tidak adanya lowongan pekerjaan didunia formal sehingga responden memilih untuk terjun pada usaha informal seperti usaha informal.

9. Karakteristik Pelaku Informal Jawa Timur Berdasarkan Jumlah Asset Dalam Usaha

Data hasil penelitian menunjukkan bahwa pelaku usaha informal yang mimiliki asset $\mathrm{Rp} 1$ juta - 50 juta dengan persentase sebesar $71,2 \%$, selain itu yang memiliki total asset sebesar 100 sampai 800 juta adalah pelaku informal dengan persentase sebesar $22,4 \%$, sisanya adalah pelaku informal yang memiliki total asset antara 51 juta -100 juta dengan persentase sebesar $6,4 \%$.

Hal ini dapat diambil kesimpulan bahwa mayoritas pelaku informal di Jawa Timur memiliki jumlah asset sebesar 1 juta -50 juta, hasil ini sejalan dengan UU no 20 tentang UMKM di Indonesia.

10. Karakteristik Pelaku Informal Jawa Timur Berdasarkan Tahun Pendirian Usaha

Data hasil penelitian menunjukkan bahwa mayoritas usaha yang dilakukan oleh pelaku usaha informal didirikan pada tahun antara 2011 hingga 2018 yaitu sebanyak $61,2 \%$, dan usaha yang dbangun pada tahun 2000 hingga tahun 2010 sebanyak 20,8\%, sisanya sebanyak $17,2 \%$ merupakan usaha lama yang dibangun sebelum tahun 2000.

Dapat disimpulkan bahwa usaha yang dilakukan pelaku informal mayoritas adalah usaha 


\section{JURNAL EKONOMI DAN MANAJEMEN \\ P-ISSN: 2598-9022/ E-ISSN: 2598-9618 \\ Available at:}

http://e-journal.unipma.ac.id/index.php/capital

baru berjalan diatas tahun 2000

yang dilakukan oleh generasi muda.

11. Karakteristik Pelaku Informal Jawa Timur Berdasarkan Bentuk Badan Usaha

Hasil penelitian menunjukkan bahwa usaha yang dilakukan oleh pelaku usaha informal sebesar $60 \%$ adalah usaha milik perorangan/sendiri, dan $8,4 \%$ berbentuk perseroan terbatas (PT), sebesar $7,6 \%$ adalah usaha berbentuk perkongsian $(\mathrm{CV})$, dan sebesar $5,2 \%$ adalah usaha berbentuk koperasi dan sisanya sebesar $16,8 \%$ adalah bentuk usaha dengan bentuk badan hukum lainnya.

Dapat disimpulkan bahwa usaha informal Jawa Timur mayoritas adalah usaha milik perorangan/pribadi, hal ini mengindikasikan bahwa usaha tersebut banyak didirikan secara mandiri dan berasal dari pengalaman pribadi tanpa ada kerjasama dengan pihak lain dan bentuk badan usahapun tradisional serta belum berbadan hukum.
12. Karakteristik Pelaku Informal Jawa Timur Berdasarkan Sektor Bisnis yang Dijalankan

Hasil penelitian menunjukkan bahwa sebesar 38,4\% usaha yang dijalnkan oleh informal Jawa Timur adalah usaha dalam bidang perdagangan dan jasa. sisanya sebesar 26,8\% dalam bidang transportasi, industri, kontruksi dan juga pertanian, dan sebesar $24 \%$ usaha dalam menyediakan barangbarang untuk konsumen.

Dapat disimpulkan bahwa mayoritas usaha yang dilakukan oleh pelaku usaha informal adalah usaha dalam bidang perdagangan dan jasa, hal ini disebabkan karena usaha tersebut mudah untuk dijalankan dan merupakan jasa yang dibutuhkan oleh para konsumen setiap hari, sehingga berpeluang besar bagi pelaku informal untuk menjalankannya.

\section{E. KESIMPULAN}

Dari hasi penelitian yang telah dilakukan, maka dapat disimpulkan bahwa :

1. Profil pelaku usaha informal di Jawa Timur dapat dilihat dari 


\section{JURNAL EKONOMI DAN MANAJEMEN \\ P-ISSN: 2598-9022/ E-ISSN: 2598-9618 \\ Available at:}

http://e-journal.unipma.ac.id/index.php/capital

beberapa aspek, yaitu: perbedaan gender, status perkawinan, distribusi umur, tingkat pendidikan, kepemilikan keahlian sebelum berwirausaha, jumlah pekerja fulltime dalam usahanya, pendapatan, lama usaha yang dilakukan responden, jumlah asset dalam usaha, tahun pendirian usaha, bentuk badan usaha, jenis sector bisnis

2. Dari berbagai aspek tersebut maka dapat diambil kesimpulan :

a. Dari aspek perbedaan gender, dapat disimpulkan bahwa pelaku usaha informal di Jawa Timur didominasi oleh responden dengan jenis kelamin perempuan dengan persentase sebesar 50,8\%

b. Dari aspek status perkawinan, dapat disimpulkan bahwa pelaku informal di Jawa Timur didominasi oleh responden yang telah menikah dengan persentase sebesar $81.6 \%$,

c. Dari aspek distribusi umur, dapat disimpulkan bahwa pelaku informal di Jawa Timur didominasi oleh responden yang berusia 40-49 tahun, dengan persentase sebesar 37,6\%.

d. Dari aspek tingkat pendidikan, dapat disimpulkan bahwa pelaku informal di Jawa Timur didominasi oleh responden dengan tingkat pendidikan lulusan SLTA dengan persentase sebesar $62,8 \%$.

e. Dari aspek kepemilikan keahlian sebelum berwirausaha, dapat disimpulkan bahwa pelaku informal Jawa Timur dengan persentase yang sama yaitu sebgaian responden telah memiliki keahlian berwirausaha dan sebagian belum memiliki keahlian sebelum berusaha.

f. Dari aspek jumlah pekerja fulltime dalam usahanya, dapat disimpulkan bahwa pelaku informal jawa timur hanya memiliki satu orang pekerja dalam operasional usahanya, dengan persentase sebesar $40,8 \%$

g. Dari aspek pendapatan, dapat disimpulkan bahwa pelaku 


\section{JURNAL EKONOMI DAN MANAJEMEN \\ P-ISSN: 2598-9022/ E-ISSN: 2598-9618 \\ Available at:}

http://e-journal.unipma.ac.id/index.php/capital

informal di Jawa Timur

mayoritas memiliki penda-

patan antara 11 juta hingga 50

juta pertahun dengan

persentase sebesar $28,4 \%$.

h. Dari aspek lama usaha yang dijalankan, dapat disimpulkan bahwa pelaku informal Jawa Timur telah berusaha selama lebih dari 10 tahun, dengan persentase sebesar 55\%.

i. Dari aspek jumlah asset dalam usaha, dapat disimpulkan bahwa pelaku informal Jawa Timur mayoritas memiliki asset sebesar 1 juta -50 juta dengan persentase sebesar $71,2 \%$.

j. Dari aspek tahun pendirian usaha, dapat disimpulkan bahwa pelaku informal Jawa Timur mayoritas mendirikan usaha pada tahun 2011 hingga 2018 dengan persentase sebesar $61,2 \%$.

k. Dari aspek bentuk badan usaha, dapat disimpulkan bahwa pelaku informal jawa timur mayoritas memiliki badan usaha berbentuk perseorangan/pribadi, dengan

persentase sebesar $60 \%$.

1. Dari aspek jenis sektor bisnis, dapat disimpulkan bahwa pelaku usaha informal di Jawa Timur mayoritas berusaha dalam sektor perdagangan dan jasa, dengan persentase sebesar $38,4 \%$.

3. Hasil penelitian ini dapat digunakan sebagai dasar pengambilan kebijakan dalam pengembangan sektor informal di provinsi Jawa Timur.

\section{DAFTAR PUSTAKA}

Alisjahbana. 2006. Marginalisasi Sektor Informal Perkotaan. Surabaya: ITS Press.

Ascarya, Yumanita, Diana.2017.The Profile of Micro, Small, and Medium Enterprises in Indonesia and the Strategy to Enhance Islamic Financial Services through Baitul Maal wa Tamwi. Proceedings of the 2nd Islamic Conference: Islamic Science University of Malaysia.

Badan Pusat Statistik (bps) diakses dari http://www.bps.go.id/, diakses pada tanggal 30 desember 2018

Boeke (1953), Economic and Economic Policy of Dual 
Societies: As Exemplified by Indonesia, International Secretariat, Institute of Pacific Relations, New York

Adam, Felecia P. 2017. Keragaman sektor informal dalam hubungannya dengan migrasi masuk dan remitan (kasus di negeri Batu Merah, kota Ambon). Journal Paramida Kependudukan dan Pengembangan Sumber Daya Manusia. Vol. X No. 2

Geertz, Clifforrd (1963), Peddlerrs and Princes: Social Change and Economic Modernization in Two Indonesian Towns, The University of Chicago Press, Chicago.

Gilbert, Alan and Josef Gugler, 1996. Urbansiasi dan Kemiskinan di Dunia Ketiga. Yogyakarta: Tiara Wacana.

Hidayat.(1978), Peranan Sektor Informal Dalam Struktur Perekonomian Daerah Yogyakarta, Pusat Penelitian Sumberdaya Manusia dan Lingkungan, Universitas Padjadjaran, Bandung

Munkner, Hans $\mathrm{H}$ dan Thomas Walter, 2001. Sektor Informal Sumber Pendapatan Bagi Kaum Miskin, dalam Menggempur Akar-Akar Kemiskinan (Izzedin Bakhit dkk), Attacking the Roots of Poverty, Jakarta: Yakoma PGI.

Riat, Asis. Zulva, Khusnatul.2016. Profil Sektor Informal di
Kabupaten Ponorogo. Journal Al Tijarah. Vol. 2, No. 1.

Richardson, H. (1984), “The Role of The Urban Infor mal Sector: An Overview, di dalam Regional Development Dialogue, Vol.5, No.2, h. 3-40.

Sugiyono. (2015). Metode penelitian Manajemen. Bandung: Penerbit Alfabeta.

Undang-undang republik Indonesia nomor 20. 2008.Usaha Mikro, Kecil, dan Menengah. 